This item was submitted to Loughborough's Research Repository by the author.

Items in Figshare are protected by copyright, with all rights reserved, unless otherwise indicated.

\title{
Managing the lifecycle of your robot
}

PLEASE CITE THE PUBLISHED VERSION

PUBLISHER

(c) Taylor and Francis

VERSION

SMUR (Submitted Manuscript Under Review)

\section{PUBLISHER STATEMENT}

This work is made available according to the conditions of the Creative Commons Attribution-NonCommercialNoDerivatives 4.0 International (CC BY-NC-ND 4.0) licence. Full details of this licence are available at: https://creativecommons.org/licenses/by-nc-nd/4.0/

\section{LICENCE}

CC BY-NC-ND 4.0

\section{REPOSITORY RECORD}

Sinclair, Murray A., and Carys E. Siemieniuch. 2019. "Managing the Lifecycle of Your Robot". figshare. https://hdl.handle.net/2134/17539. 


\title{
MANAGING THE LIFECYCLE OF YOUR ROBOT
}

\author{
M.A. Sinclair \& C.E. Siemieniuch,
}

ESoS Research Group

School of Electrical, Electronic \& System Engineering

Loughborough University of Technology

'Robot' for this paper is assumed to be a cognitive device, acting as a co-worker within a team of human workers: a mobile device, with a degree of autonomy, interchangeable prostheses, interacting freely with surrounding humans, in a civilian environment.

An exemplar lifecycle is the MoD's CADMID lifecycle., and the paper concentrates on the In-service phase, for reasons of space. The approach is from a management perspective; a road-map is provided to acquire a robot, to put it to work, and to support both it and the team during its in-service phase. The emphasis is on what management needs to consider and the structures that need to be in place in order to run this process.

\section{Introduction}

The development of robotic technology proceeds apace; however, it is largely driven by engineers thinking in engineering development terms. At some point it becomes necessary to look beyond the purely engineering development effort, impressive as it is, and contemplate the utilisation of robots in society. It is with this aspect that this paper is concerned. First, an exemplar co-working scenario is presented, and then some of the management issues entailed in this scenario are explored.

Much has been made of the potential use of robots in assistive living, both to enable the elderly, and other challenged individuals, enabling them to live at home and relieving the demand on care and medical services. Of potentially more economic significance will be the role of robots in value-creation in 
society, working in conjunction with human beings in teams. It may be argued that that is happening already on production lines; true, but the robots are encaged, performing repetitive tasks with little autonomous judgement involved. The role for robots in this paper is as a co-worker, carrying out joint tasks with humans, and single tasks in parallel.

Unfortunately, there are no robots in production of significant capability to provide practical experience. For this reason, a scenario approach is used by which a management process could be generated, based on experience in other complex products. Necessarily, this is an abstract process, requiring further elaboration as better understanding is gained.

There are three significant scenarios that can be envisaged as listed below; we discuss one in some detail, and then amend the discussion for the other cases. The scenarios are:

- Assistive living: for example, an elderly person (or other reducedcapability person) is provided with a robot to enable that person to live at home and receive moment-by-moment support, complementing that provided by other human-based care services.

- Co-working in teams: a team comprising humans and one or more robots work together carrying out joint tasks with humans, and single tasks in parallel with humans. These teams need not be constrained to production facilities; fieldwork teams in the utilities such as gas, electricity and energy, road and rail maintenance and so on could also have robot co-workers. Robots may well be restricted mainly to the 4D tasks; dull, dirty, dangerous and dark, also fetching, lifting and carrying, but they will be doing this in close proximity to human beings, and, perhaps, other robots too. The 'BigDog' robot is a prototype for this role (www.engadget.com/2013/02/28/bigdog-robot-has-an-arm-nowrun/).

- Distributed working: the Internet of Things case, where a cognitive device is part of a system of systems, perhaps embedded, whose decisions interact with humans in accomplishing a purpose. The robot itself may be a geographically-distributed device.

The scenario chosen for exploration is co-working. For simplicity, we assume there is one robot in a workgroup including several humans, and that this workgroup is functioning within a larger organisation, carrying out maintenance tasks at any of a number of locations, all different. The robot itself is assumed to be mobile, equipped with prostheses (one or more) to enable it to be a tool-user. Furthermore, we assume that the robot has been equipped with sufficient software to enable it to operate, for most tasks, at level 6 on Sheridan's scale (Sheridan 1980, Sheridan 1994, Parasuraman, Sheridan et al. 2000): “allows the human a restricted time to veto before automatic execution [of the decision or task]", or perhaps at level 7 "executes automatically, then necessarily informs the human". It should be noted that this implies that the robot, working among 
people, necessarily must be capable of ethical behaviour, though perhaps not at the level to be expected of humans (Sullins 2006, Abney 2012, Asaro 2012). This is necessary for its co-workers to trust it when it is working autonomously. For safety reasons (see Table 1), it is assumed that the robot continuously records its working environment and its work, irrespective of privacy concerns.

Furthermore, if for illustration purposes we adopt the MoD CADMID lifecycle as shown in Figure 1, the paper only addresses the second last of these phases.

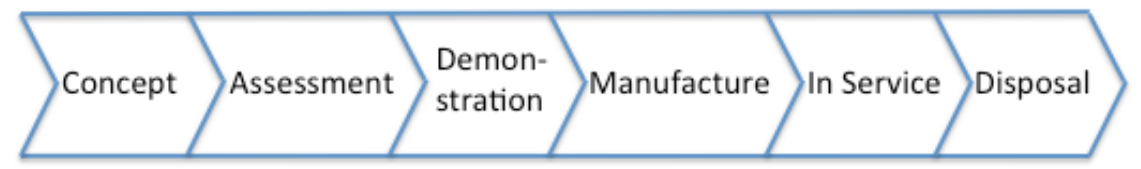

Figure 1: The CADMID lifecycle, utilised by the UK Ministry of Defence.

We may now propose a process for managing the robot over its working life in the organisation, as shown in Figure 2 below. This diagram is predicated on the assumption that the organisation that supports the work group also plans the insertion of the robot(s) into the workgroup. It will be noted that a considerable support effort is required before the robot is put to use within the work group.

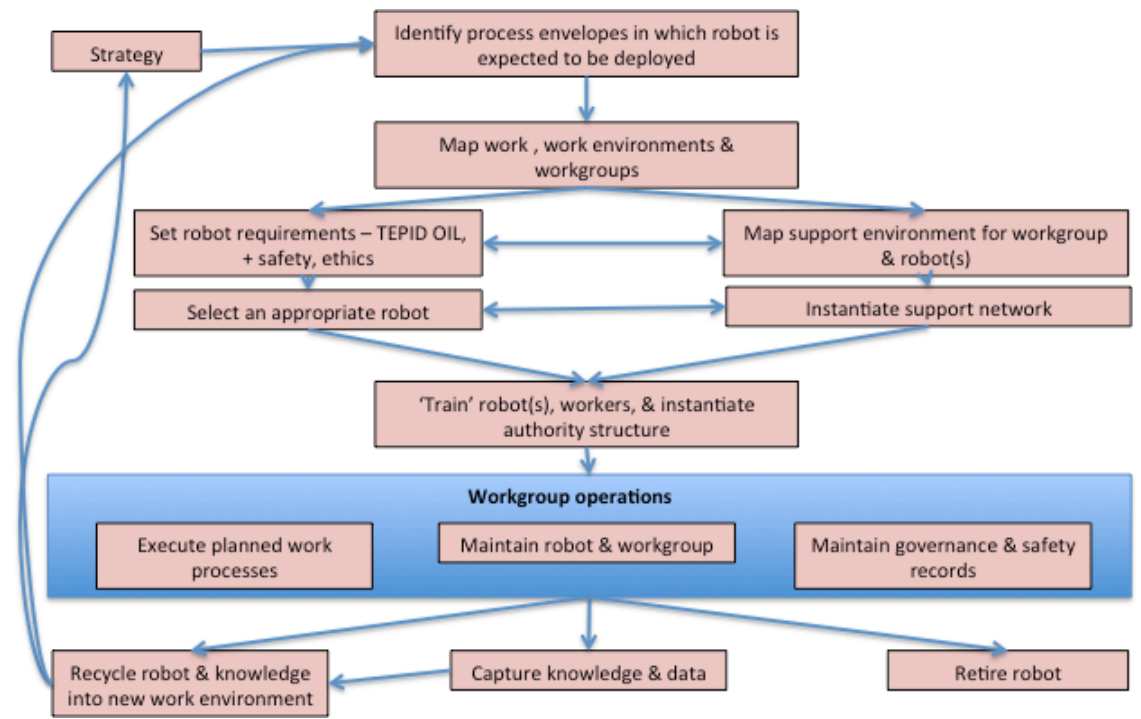

Figure 2: A high-level process to manage robot co-workers. It is assumed that the robot is obtained from a supplier; not built in-house. See Figure 3 and the text below for an explanation of TEPID OIL.

Figure 3 below provides a little more detail about Figure 2 above. It outlines the steps from strategy to work group operations in relation to a notional timescale, and introduces the 'TEPID OIL' acronym first adopted by the Ministry of 
Defence in the UK, in the form of a 'Mackley diagram' (Mackley, Barker et al. 2007, Mackley 2008). TEPID OIL covers the following aspects of capability:

Training, Equipment, Personnel, Information, Doctrine (in civilian terms, this equates to strategy and policy; for the purposes of this document it also includes ethics), Organisation Infrastructure (for this document, this term includes interoperability), and Logistics

Together, these aspects enable an organisation to deliver a capability.

\begin{tabular}{|c|c|c|c|c|c|c|c|c|}
\hline & Training & Equipment & Personnel & Information & Doctrine & Organisation & Infrastructure & Logistics \\
\hline $\begin{array}{l}\text { LO: } \\
\text { Hour }\end{array}$ & & $\begin{array}{l}\text { Maintain } \\
\text { robot \& } \\
\text { support }\end{array}$ & $\begin{array}{l}\text { Work-gp } \\
\text { starts } \\
\text { wgrk }\end{array}$ & $\begin{array}{c}\text { Process } \\
\text { data } \\
\text { available }\end{array}$ & $\begin{array}{c}\text { Continue } \\
\text { governance } \\
\text { checks }\end{array}$ & $\begin{array}{l}\text { Support } \\
\text { network } \\
\text { deployed }\end{array}$ & $\begin{array}{c}\text { Support } \\
\text { infrastructure } \\
\text { established }\end{array}$ & $\begin{array}{l}\text { Logistics } \\
\text { operating }\end{array}$ \\
\hline $\begin{array}{l}\text { L1: } \\
\text { Day }\end{array}$ & & & $\begin{array}{c}\text { Release } \\
\text { work-gp } \\
\text { to process }\end{array}$ & & & & $\uparrow$ & \\
\hline $\begin{array}{l}\text { L2: } \\
\text { Month }\end{array}$ & $\begin{array}{l}\text { Context } \\
\text { specific } \\
\text { training }\end{array}$ & $\begin{array}{l}\text { Prove robot } \\
\text { support } \\
\text { eqpt }\end{array}$ & & $\begin{array}{l}\text { Adapt } \\
\text { process for } \\
\text { robot(s) }\end{array}$ & $\begin{array}{l}\text { Implement } \\
\text { governance } \\
\text { checks }\end{array}$ & $\begin{array}{l}\text { Implement } \\
\text { governance } \\
\text { support }\end{array}$ & & $\begin{array}{l}\text { Logistics } \\
\text { elements } \\
\text { in place }\end{array}$ \\
\hline $\begin{array}{l}\text { L3: } \\
\text { Year }\end{array}$ & $\begin{array}{c}\uparrow \\
\text { Generic } \\
\text { training }\end{array}$ & $\begin{array}{c}1 \\
\text { Acquire } \\
\text { robot \& } \\
\text { support }\end{array}$ & $\begin{array}{c}\text { Personnel } \\
\text { Rselection }\end{array}$ & $\begin{array}{l}\text { Acquire } \\
\text { training }\end{array}$ & $\begin{array}{l}\text { Identify } \\
\text { governance } \\
\text { checks }\end{array}$ & & $\begin{array}{l}\text { Plan support } \\
\text { Infrastructure }\end{array}$ & $\begin{array}{l}\text { Loglstics } \\
\text { req'ts } \\
\text { defined }\end{array}$ \\
\hline $\begin{array}{l}\text { L4: } \\
\text { Decade+ }\end{array}$ & & & & & $\begin{array}{l}\text { strategy, } \\
\text { safety, } \\
\text { ethics } \\
\text { elucidated }\end{array}$ & & & \\
\hline
\end{tabular}

Figure 3 A Mackley diagram to plan the introduction of a robot into a work group, indicating that the planning may have to start a decade before the work group commences operation, and that many sub-processes will have to happen concurrently, placing considerable emphasis on overall project management. A corollary is that for this to be an efficient process, the management of knowledge will be a key issue.

Fig. 3 implies a number of lessons, as listed below.

- Planning for the introduction of a robot into a workgroup will require considerable lead time.

- Many process must happen concurrently; this is driven not just for efficiency reasons, but because of the rapid pace of development of robot technology. Too much time spent on this process likely will result in a nearobsolescent outcome.

- All of these sub-processes are necessary. It is difficult to see how an effective work group could be delivered if any of these is missed.

- While it is strategy that commences the whole exercise, strategy necessarily must be a continuous process, because the outcome is a complex system, and because of the rate of development of technology, as indicated above. The better is the strategic grasp at the beginning, the less likely will be the need for reworking in the sub-processes. 
Fig 4 below shows a generic organisational structure that distributes authority and responsibility to run the process in Figs 2 and 3 on a continuous basis.

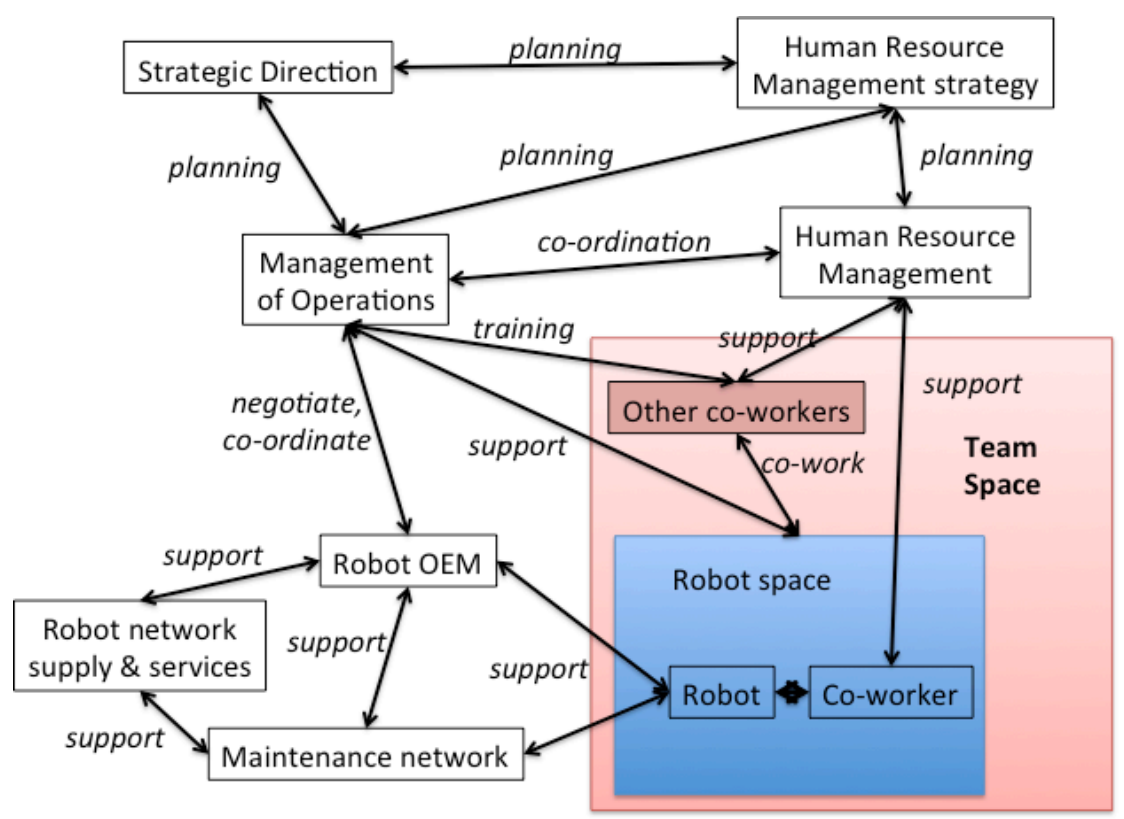

Figure 4: The diagram represents a network for authority and responsibility to support the work group using the processes outlined in Figures $2 \& 3$. These functions may be distributed across different organisations.

At right is a structure to provide human resource support to the individuals in the team as a whole, including those who work directly with the robot. This corresponds to the personnel column in Fig. 3. Along the bottom is the subprocess to support the robot, delivering upgrades, maintenance and probably technical support to those managing operations. This corresponds to the equipment column in Fig. 3, and is separated out because of the complexities and specialisms of robot engineering. The main diagonal embraces the rest of the columns in Fig. 3, and most of the process in Fig. 2. It is also the region in which most of the governance issues will be addressed.

Because of the high-level abstractions in Figures 2 to 4, it is possible to apply these diagrams to the other two scenarios listed earlier, albeit with some changes in emphasis. For example, in the Assisted Living scenario, it is likely that the management of operations will find itself with some technological challenges, implying that some of the robot-orientated authority and responsibility aspects of management would be better placed within the horizontal, equipment supply and maintenance domain. Furthermore, given that a proportion of people would prefer to organise their own care, especially in the early stages, and the likely 
cost of these robots, it is likely that the best business model would be one in which leasing is the fundamental arrangement to provide care.

Likewise for distributed robotic systems; the problem here is that it is possible that some of the cross-links between the strands in Figure 4 will be contractbased. Because this redistribution might be across jurisdictions, it is likely that some regulatory and standards activity will be required for this scenario.

Finally, we consider some of the safety aspects that must be addressed in the diagrams above, from an ethical standpoint:

Table 1: A listing of co-worker protection requirements

\begin{tabular}{|c|c|c|}
\hline No. & Keyword & Principle \\
\hline 1 & Authority 1 & $\begin{array}{l}\text { Whatever the application, the human party shall have the } \\
\text { highest authority. }\end{array}$ \\
\hline 2 & Authority 2 & $\begin{array}{l}\text { All decisions and action plans originated by robots shall } \\
\text { be under the supervision of a human party, who shall } \\
\text { take responsibility for these. }\end{array}$ \\
\hline 3 & Authority 3 & $\begin{array}{l}\text { The last person to issue a command to a robot shall take } \\
\text { responsibility for the outcomes; other stakeholders may } \\
\text { also be included. }\end{array}$ \\
\hline 4 & Authority 4 & Robots shall not 'force' human response. \\
\hline 5 & Safety 1 & $\begin{array}{l}\text { A robot shall not deliberately cause injury, neither } \\
\text { physiological nor psychological. }\end{array}$ \\
\hline 6 & Safety 2 & $\begin{array}{l}\text { Any contact between robots and humans shall be by } \\
\text { 'controlled collisions' (e.g. touching, hand-overs, etc.). }\end{array}$ \\
\hline 7 & Safety 3 & $\begin{array}{l}\text { Any learning undertaken by robots shall be subject to } \\
\text { verification and validation (V\&V) to ensure continuous } \\
\text { compliance with Safety } 1 \& 2 \text {. }\end{array}$ \\
\hline 8 & Safety 4 & $\begin{array}{l}\text { Periodic inspection of robots shall be undertaken, to } \\
\text { ensure compliance with Safety } 1,2 \text { \& } 3 \text { above. }\end{array}$ \\
\hline 9 & Safety 5 & $\begin{array}{l}\text { Robots shall not be abandoned by their designers, } \\
\text { developers, manufacturers and/ or owners until they are } \\
\text { withdrawn from service. }\end{array}$ \\
\hline
\end{tabular}




\begin{tabular}{|c|c|c|}
\hline No. & Keyword & Principle \\
\hline 10 & Safety 6 & $\begin{array}{l}\text { Where a failure of the cognitive device(s) within a } \\
\text { system might lead to a critical safety situation for the } \\
\text { user, a back-up system to mitigate the critical safety } \\
\text { situation shall be provided. }\end{array}$ \\
\hline 11 & Safety 7 & $\begin{array}{l}\text { The output of a cognitive device shall not be utilised in } \\
\text { any cultural region outside those formally considered } \\
\text { during the design or the tailoring during the } \\
\text { implementation of the device in a system. }\end{array}$ \\
\hline 12 & $\begin{array}{l}\text { Anthropo- } \\
\text { morphism } 1\end{array}$ & $\begin{array}{l}\text { Unless legally permitted, the design and operation of } \\
\text { cognitive devices shall eschew anthropomorphism } \\
\text { intended to delude humans interacting with them. }\end{array}$ \\
\hline 13 & $\begin{array}{l}\text { Anthropo- } \\
\text { morphism } 2\end{array}$ & $\begin{array}{l}\text { Designers of robots should avoid anthropomorphism } \\
\text { where this might lead to unnatural or socially } \\
\text { compromising behaviour, and where it is not clearly } \\
\text { required to exercise the system's functionality. }\end{array}$ \\
\hline 14 & $\begin{array}{l}\text { Technology } \\
\text { addiction } 1\end{array}$ & $\begin{array}{l}\text { Designers of robots should avoid creating systems that } \\
\text { could lead to addictive behaviours in their human users }\end{array}$ \\
\hline 15 & $\begin{array}{l}\text { Social } \\
\text { exclusion } 1\end{array}$ & $\begin{array}{l}\text { Those providing support systems that include robotics } \\
\text { should ensure that these do not lead to social exclusion } \\
\text { and an increased potential for human neglect. }\end{array}$ \\
\hline 16 & $\begin{array}{l}\text { Social } \\
\text { exclusion } 2\end{array}$ & $\begin{array}{l}\text { Where users are dependent on robots, the design and } \\
\text { employment of these shall not 'trap' users in one } \\
\text { location because of insufficient power provision. }\end{array}$ \\
\hline 17 & $\begin{array}{l}\text { Represent- } \\
\text { ation } 1\end{array}$ & $\begin{array}{l}\text { For those users likely to be physiologically or } \\
\text { cognitively dependent on robots, prior to their } \\
\text { introduction, discussions with the patients, or their } \\
\text { representatives, shall take place. }\end{array}$ \\
\hline 18 & $\begin{array}{l}\text { Represent- } \\
\text { ation } 2\end{array}$ & $\begin{array}{l}\text { For 'patients' as defined in Representation } 1 \text {, provision } \\
\text { shall be made for the patient to have an ombudsman or } \\
\text { other representative for the duration of the care system. }\end{array}$ \\
\hline 19 & $\begin{array}{l}\text { Data } \\
\text { protection } 1\end{array}$ & $\begin{array}{l}\text { The capture of data of a personal nature by a robot shall } \\
\text { comply with relevant legislation, and shall be agreed } \\
\text { with end-users of the system before it is commissioned. }\end{array}$ \\
\hline
\end{tabular}




\begin{tabular}{|c|l|l|}
\hline No. & Keyword & \multicolumn{1}{c|}{ Principle } \\
\hline 20 & $\begin{array}{l}\text { Data } \\
\text { protection 2 }\end{array}$ & $\begin{array}{l}\text { Personal data captured by the robot shall be protected } \\
\text { according to current legislation. }\end{array}$ \\
\hline 21 & $\begin{array}{l}\text { Data } \\
\text { protection 3 }\end{array}$ & $\begin{array}{l}\text { Where robots interface to the internet or other } \\
\text { information systems, data security shall be paramount }\end{array}$ \\
\hline 22 & $\begin{array}{l}\text { Data } \\
\text { protection 4 }\end{array}$ & $\begin{array}{l}\text { Access to personal data captured by robots shall only be } \\
\text { accessible to the person concerned, to those cognitive } \\
\text { agents authorised to have access and to other persons } \\
\text { given legal permission to have access. }\end{array}$ \\
\hline
\end{tabular}

It seems evident that there is a long way to go before robots as co-workers become likely in work groups. For other reasons not discussed here and due to liability, personhood, ethics and culture, we believe robots will always be subservient to humans. It is also evident that for members of the IEHF to be involved in this form of HMI, some increase in understanding will be needed.

\section{References}

Abney, K. 2012. Robots, ethical theory and metaethics: a guide for the perplexed. Robot ethics. P. Lin, K. Abney, G.A. Bekey. Cambridge, MA: 3554.

Asaro, P. M. 2012. A body to kick, but no soul to damn: perspectives on robotics. Robot ethics. P. Lin, K. Abney, G.A. Bekey. Cambridge, MA MIT Press: 169-186.

Mackley, T. 2008. Concepts of agility in Network Enabled Capability. Realising Network Enabled Capability. Oulton Hall, Leeds, UK, BAE Systems.

Mackley, T., S. Barker \& P. John 2007. Concepts of agility in Network Enabled Capability. The NECTISE project. Cranfield, Cranfield University, UK 8.

Parasuraman, R., T. B. Sheridan \& C. D. Wickens 2000. "A model for types and levels of human interaction with automation." IEEE Transactions on Systems, Man \& Cybernetics 30(3): 286-297.

Sheridan, T. B. 1980. "Computer control and human alienation." Technology Review(October): 61-70.

Sheridan, T. B. 1994. Human supervisory control. Design of work and development of personnel in advanced manufacturing. G. Salvendy and W. Karwowski. New York, John Wiley \& Sons. Ch. 3: 79-102.

Sullins, J. P. 2006. "When is a robot a moral agent?" International Review of information Ethics 6(1): 24-30. 